\title{
MANAGEMENT OF LAND AND WATER RESOURCES FOR ECOLOGICAL SECURITY
}

\author{
*D. Rudrappan
}

\begin{abstract}
Management of land and water resources has emerged as a vital issue in promoting bio-diversity and ecological security programmes. The basic message of ecological security is not of containing development to save ecology but of managing ecology to promote development. What is good for development is equally good for ecology. Developmentalists point out that development not only provides for all-round exponsion of the economy but also builds capacity for improving the quality of ecology. Therefore the basic issue is that the wheel of development must move on but it should advance within the supportive capacity of the ecosystem. Any desired development should have the ingredients of efficiency, equity and democracy. When this is done, the people tend to take ecology - friendly decisions. The validity of the above ideas is tested through a case study on Palor river basin. Management of Palar river basin against water pollution requires effective monitoring and implementation of protective measures not only for the management of water care but also for the land care as well. In doing so, this study analyses the grave problems posed by fannery effluents and suggest measures for achieving susfainable development, environment and livelihood security.
\end{abstract}

* Dept. of Economics, Presidency College, Chennai - 5. T.N. 


\section{Introduction}

Land and water are prime natural resources and precious national assets. They are part of our ecological system. The basic message of sustainable development is that the wheel of development must move on but it should advance within the supportive capacity of the ecosystem. The present needs are to be met without compromising the ability of future generations to meet theirs.' The development ecology debate that is raging for decades has started with a concern for the damage to ecology that modern development has caused. Eco-Fundamentalists insist on moderating the pace of development. Increasing demands and competing needs of mankind are seen as damaging the natural resources such as land, water and air upon which all life depends. ${ }^{2}$

\section{Preservation of Ecology}

However, development economists have pointed out that development alone builds capacity for improving the quality of ecology. Therefore, the development process should not be stopped in the interests of both economy and ecology and any policy package must have a goal of an accelerated development and better environment management ${ }^{3}$ The aim is not of limiting development to save ecology but of managing land and water resources effectively to promote development.

Generally civilizations flourished around water sufficient ecologies and withered under improper management of water resources. Conservation and efficient management of water resources is crucial for countries with predominant agrarian economies where development of sustainable agriculture is essential for over all growth, alleviation of poverty and food security. As monitoring and management of water resource is vital for the sustenance of mankind, tackling water scarcity and providing quality water to human beings is a priority agenda for any Government, across the globe. In the event of water becoming scarce, meeting the competing demand for water is an uphill task for many administrations. Apart from causing restlessness to women and the family, water scarcity triggers social unrest, migration, reduction of livelihood options, denial of education and disturbance of day today life of the people. Therefore, it is of utmost importance to protect the quality and quantity of available surface water as well as ground water for ensuring sustainable development and environment security.

\section{Need for Water Care and Land Care}

India is a vast country with different agro-climatic regions. About 70 per cent of its arable land depends entirely on rainfall for crop production and this 
requires renewed attention on conservation of water and its integrated management. for optimal use. The country receives an annual average rainfall of $1200 \mathrm{~mm}$ which, when multiplied by the geographical area, works out to $400 \mathrm{~m}$.ha.m. After surface run-off and seepage, the available ultimate irrigation potential of the country has been estimated at $113 \mathrm{~m} \cdot$ ha. $^{4}$. Similarly, the available irrigation potential of Tamil Nadu has been estimated at 3900 thousand hectare metres ${ }^{5}$. In the context of meagre availability of water, various measures have to be devised for conserving every drop of rainwater. Strategies to increase water use efficiency involve three aspects viz., water management, soil management and crop management. All measures should aim at increasing per unit returns from water including rain water, surface water and ground water. Agricultural resources in several areas have been severely degraded. Signs of agro eco-system stress and even its break down are abundant. Intensive cultivation of land without conservation of soil fertility and soil structure would lead, ultimately, to the springing up of deserts. Kanvar and Bali have estimated that 90 million hectares of land suffer from water erosion, 50 million hectares from wind erosion, 7 million hectares are affected by salinity and alkalinity, and 20 million hectares suffer from flooding. Thus, 167 million hectares or $51 \%$ of the total land surface suffers from soil degradation. ${ }^{6}$

\section{The Problem of Waste Fluxes in Palar River Basin}

Unbridled environmental degradation has been taking place for a long time on account of tannery effluents released from the centuries old leather tanning industries established in Ranipet tannery belt area of Vellore district situated in Palar river basin, Tamil Nadu. The discharge of the untreated tannery solid wastes and liquid wastes has affected the surface and ground water level alarmingly beyond the permissible limit. Though two types of tanning processes are in vogue, most of the tanners opt for metal tanning process for its quick process and good effect. In addition to the proliferation of leather tanning industries, the adoption of mineral tanning process has compounded the problem and degraded the environmental security of the region further.

The study area, Ranipet is situated west of Madras at about 100 kilometers. The area is drained by the Palar river and its tributaries and the main source of irrigation is well water which plays a significant role in the agricultural development of the region. The ground water flow follows the topographic configuration towards the Palar river. The elevations of water table vary between 183 and 133 metres above sea level. 


\section{Discussion}

As tanning industry has been using mostly metallic process, variety of chemicals and metals are used. Much water is required to remove the salt from the salted hides. It is estimated that nearly 4 tonnes of salt is removed from every 10 tonnes of salted hides. In the same way $2.6 \mathrm{gms}$ of chromium is used for every $1 \mathrm{~kg}$ of leather processing. Thus, salt, chromium along with other untreated effluents are discharged into the open land and the low lying areas causing high salinity, health hazards and ecological imbalance. It is estimated that out of the State's total number of 662 tanneries, in the Ranipet region alone, 209 tanneries with a processing capacity of about $2,89,000 \mathrm{~kg}$ per day discharge 300 million litres of effluents on an average along with $300 \mathrm{~kg}$ of solid waste for every tonne of processed hide. Further, 105 chrome-tanning industries on an average release 490 tonnes of chromium along with the discharged effluents.'

A study of the quality of water in dug wells and bore wells around the tannery industries revealed physical properties of water such as dark coloured water with pungent odour and saltish taste. Further, the study pointed out the existence of chemical properties such as alkaline with $\mathrm{pH}$ value ranging from 7 to 8.5 , the electrical conductivity of the ground water ranging from 220 to 9300 microsiemens $/ \mathrm{cm}$ at $250 \mathrm{C}$ and the same level of distribution of chloride in the study area. Most of the water samples fall in the categories of C4S3 to C4S4, thereby indicating high salinity and as such is found unsuitable for irrigation purpose. Similarly lead and chromium levels are uniformly high and there exists a positive correlation between the concentrations of lead and chromium. Thus, the quality of water has been found affected with high levels of inorganic total dissolved solids (the permitted TDS level is $2,100 \mathrm{mg} / \mathrm{l}$ ) and unfit for all purposes. The situation has reached alarming proportions rendering thousands of hectares of fertile land sterile. The effects of water pollution are seen in the stunted growth of crops, poor germination, discoloration, leaf burn, poor quality of fruits and grains along with higher incidence of diseases among people, animals and aquatic life. Tamil Nadu Agricultural University has pointed out that tannery pollution has caused a yield loss of $75 \%$ in paddy, $52 \%$ in coconuts and $48 \%$ in sugarcane with an average income loss varying $15 \%$ to $80 \% .^{8}$

The Loss of Ecology Authority, a body set up in 1966 on the orders of Supreme Court of India to assess the damage caused by pollution in the region has awarded compensation to the environment protection schemes amounting to Rs. 3.66 crores. $^{9}$ Further, the award has led to the closure of nearly 135 tanneries, which neither had their own effluent treatment plants nor were connected to a common effluent treatment facility. Though the final award has listed a number of schemes to preserve the 
ecological balance of the river basin, these measures remain contested in the courts by the members of All India Skin and Hides Tanners and Merchants Association.

\section{Conclusions}

To prevent further threat to the eco-systems and to reverse the damage already done, a holistic approach involving following schemes is required. Relocation of certain tannery industries with salt discharging production processes; adoption of cleaner tanning technologies such as recycling of treated effluents; promotion of salt less curing process; pollution control technologies; installation of effluent treatment plants on scientific basis; use of impermeable barriers such as steel sheet piles and grout curtains to isolate toxic pollutants, water shed management for water and soil conservation; drainage works; biological reclamation succh as raising of salt tolerant trees and hedges to hold the soil in the affected area are some of the ways to minimize the negative effects of waste fluxes in the river basin, In addition to the above, setting up of eco-friendly industries for employment generation in the place of tanneries, and periodic environment impact assessment and audit by the monitoring committee are some of the other ameliorative measures to be taken up urgently and concurrently in the Palar river basin, Tamil Nadu for maintaining sustainable development, environment and livelihood security.

\section{References}

1. World commission on Environment and Development, 1987. Our common Future, Oxford University Press, Oxford,

2. United Nations Population fund, 1988, The State of World Population, New York.

3. World Bank, 1992, World Development Report: Development and Environment, Oxford University Press, Oxford.

4. Khepar, S.D. Sondhi, S.K., 1998, "Woter Management Strategies for Sustainable Development" (Ed) Ecological Agricultural and Sustainable Development, Vol: I, Dhaliwal, G.S. Ramdhowa, N.S., Chandigarth, p. 143.

5. Rudrappan, D., 2001. Changing pattern of Irrigation and its Impact on Agriculture: A study of Three Northern Districts of Tamil Nadu, Ph.D., Thesis University of Madras, Chennai - 600 005.

6. Virmani, S.M. 1991. "Promise of Wotershed Projects", Survey of Indian Agriculture, 1991, Chennai -2 , P.237. 7. Central Leather Research Institute 1998, Field Information Studies, Adyar, Chennai -
600020 .

8. Asha Krishnakumar, 2002, "An Award and Despair", Front line, Aug., 16,2002, p. 95.

9. Ibid., p. 94. 